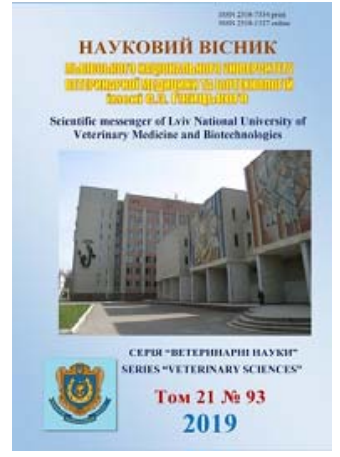

\section{Науковий вісник Яьвівського національного університету ветеринарної медицини та біотехнологій імені С.3. Гжицького. Серія: Ветеринарні науки}

Scientific Messenger of Lviv National University of Veterinary Medicine and Biotechnologies. Series: Veterinary sciences

ISSN 2518-7554 print ISSN 2518-1327 online doi: $10.32718 /$ nvlvet9318 http://nvlvet.com.ua

\title{
Monitoring of the Listeria spp. identification from the poultry products in the Dnipropetrovsk region
}

\author{
N.M. Zazharska, I.V. Borovuk \\ Dnipro State Agrarian and Economic University, Dnipro, Ukraine
}

\section{Article info}

Received 04.02.2019

Received in revised form 12.03.2019

Accepted 13.03.2019

Dnipro State Agrarian and Economic University, Yefremov Str., 25, Dnipro, 49027, Ukraine.

Tel.: +38-050-662-90-52 E-mail: zazharskayan@gmail.com drlvmbac@i.ua

\begin{abstract}
Zazharska, N.M., \& Borovuk, I.V. (2019). Monitoring of the Listeria spp. identification from the poultry products in the Dnipropetrovsk region. Scientific Messenger of Lviv National University of Veterinary Medicine and Biotechnologies. Series: Veterinary sciences, 21(93), 103-108. doi: $10.32718 /$ nvlvet 9318
\end{abstract}

Due to high mortality, listeriosis is one of the most common causes of death from illnesses associated with food, taking the second place after salmonellosis. Listeriosis, as a rule, arises as a result of consumption of contaminated products, including meat products, cheese, ready-to-eat foods. L. monocytogenes belongs to the third group of pathogenicity. Contamination by L. monocytogenes in processing of products is a constant problem in food plants. Food contamination Listeria leads to a withdrawal of products that produces economic losses. Analysis of the dynamic detection and of the differential identification of Listeria spp. in the meat products of poultry processing enterprises in Dnipropetrovsk region was conducted. The research was carried out by Dnipropetrovsk regional state laboratory of the state service of Ukraine for food safety and consumer protection. The results of bacteriological researches of meat samples which poultry plants gave for microbiological analysis during period 2008-2018 were used for monitoring. Microbiological research was carried out in accordance with valid international normative documents. The fluorescence analyzer Mini Vidas, France, the CAMP test were used for analysis. The biochemical properties of isolated microorganisms were established using BioMerieux API tests, France. Analyzing the number of researches and identification of microorganisms in the Dnipropetrovsk region for the period of 11 years, 3001 positive results out of 8172 analyzed samples were found (36.7\%). Herewith, part of positive samples goes up from $8.5 \%$ in 2008 to $77.9 \%$ in 2018. L. ivanovii was isolated in 1523 samples (18.6\%), L. inocua$833(10.2 \%)$, L. monocytogenes $-493(6 \%)$, L. seeliger $-97(1.2 \%)$, L. grayi $-36(0.4 \%)$, L. welshimeri in 19 samples of meat products ( $0.2 \%)$ out of the 8172 microbiological studies conducted over 11 years. Of the six types of identified Listeria, more than half were L. ivanovii, which is twice as high as cases with L. incocua and thrice compared to L. monocytogenes.

Key words: quality and safety, listeriosis, food toxicoinfection, Listeria spp, identification.

\section{Моніторинг виявлення Listeria spp. в м'ясопродуктах птиці у Дніпропетровській області}

\author{
Н.М. Зажарська, І.В. Боровик
}

Дніпровський державний аграрно-економічний університет, м. Дніпро, Україна

\footnotetext{
Через високу летальність, лістеріоз є однією з найчастіших причин смерті від хвороб, пов 'язаних з харчовими продуктами, посідаючи друге місие після сальмонельозу. Лістеріоз, зазвичай, виникає в результаті споживання контамінованих продуктів, у тому числі м'ясних $і$ молочних. L. топосуtogenеs відносять до третьої групи патогенності. Переробні підприємства стикаються 3 постійною проблемою обсіменіння L. топосуtogenеs у виробництві. Забруднення харчових продуктів Listeria призводить до відкликання продукиії, що спричиняє суттєві економічні збитки. Проведений аналіз динаміки виявлення $і$ диференціальної ідентифікацї Listeria spp. в м'ясопродуктах птахопереробних підприємств Дніпропетровщини. Дослідження проводили у Дніпропетровській регіональній державній лабораторії державної служби Украӥни з питань безпечності харчових продуктів та захисту споживачів. Для проведення моніторингу використовували результати досліджень проб м'яса та м'ясних продуктах птиці, які надавали виробники для мікробіологічного аналізу за 2008-2018 рр. Мікробіологічні дослідження виконували згідно з чинними міжнародними
} 
нормативними документами. Для проведення досліджень використовували флуоресцентний аналізатор “Міпі Vідаs”, Франція, проводили САМР-тест. Біохімічні властивості виділених мікроорганізмів встановлювали за допомогою АРІ-тестів виробництва ВіоМегіеих, Франція. Аналізуючи кількість проведених досліджень, виявлення та ідентифікачії Listеria у Дніпропетровській області за період 11 років, з 8172 аналізованих проб виявили 3001 позитивних результатів (36,7\%). При цьому частка позитивних проб стрімко збільшується з 8,5\% у 2008 р. до 77,9\% - у 2018 р. 38172 проведених мікробіологічних досліджень за 11 років виділяли L. ivanovii y 1523 зразках (18,6\%), L. innocua - 833 (10,2\%), L. monocytogenes - 493 (6\%), L. seeligeri-97 (1,2\%). L. grayi-36 (0,4\%), L. welshimeri y 19 зразках м'ясної продукиії (0,2\%). 3 шести видів ідентифікованих Listeria більше половини складало L. іvапоуіi, шзо удвічі більще, ніж випадків L. Іппосиа, і утричі-порівняно з L. топосуtogenes.

Ключові слова: якість і безпека, лістеріоз, харчова токсикоінфекиія, Listeria spр, ідентифікація.

\section{Вступ}

Найбільшою небезпекою для благополуччя населення є мікробне забруднення продуктів збудниками інфекційних захворювань, які передаються харчовим шляхом. Listeria monocytogenes підтверджена як одна 3 найчастіших причин смерті людини через токсикоінфекції, пов'язані з вживанням різних видів харчових продуктів, в тому числі м'яса сирого молоко, сиру, салатів з капусти, хот-догів та м'яса індички (Schwartz et al., 1988; Soriano et al., 2001; Vázquez-Boland et al., 2001; Buncic \& Avery, 2004; Kim et al., 2006; Troncoso et al., 2009; Martins \& Germano, 2011; Bover-Cid et al., 2011). Важливість L. monocytogenes як харчового патогена є двоякою: по-перше, його здатність рости при низьких температурах, i, по-друге, спроможність викликати широкий спектр симптомів у людини, включаючи спонтанні аборти. Хвороба проявляється септицемією, менінгітом, енцефалітом і внутрішньоутробною інфекцією. Найбільш поширені симптоми лістеріозу подібні до прояву гостро-респіраторних інфекцій, що, ймовірно, пояснює заниження виявлення захворювання. Хоча кількість зареєстрованих захворювань лістеріозом відносно низька, частка летальних випадків є високою - 30\% (Weinsetel, 2006; Batt, 2014; Marquis et al., 2015; Rizzuto \& Bakardjiev, 2018).

На підприємствах харчової промисловості виявлено різноманітні резервуари патогену: підлоги, водостоки, конденсат на трубах і засоби для чищення (губки, щітки), конвеєрні стрічки, пакувальне обладнання, різаки, міксери та ручні інструменти, рукавички, фартухи (Norwood et al., 2000; Weinsetel, 2006). Конструкція приміщення, інвентарю, зношене або пошкоджене обладнання обумовлюють підвищення контамінаціï Listeria, утворення біоплівок на поверхнях, де традиційні процедури очищення та дезінфекції можуть бути недостатніми (Arevalos-Sánchez et al., 2012; Saraiva et al., 2018; Gray et al., 2018).

У Регламенті ЄС № 2073/2005 про мікробіологічні критерії зазначено, що загальноприйнятий рівень L. monocytogenes - $100 \mathrm{KУО/г} \mathrm{у} \mathrm{харчових} \mathrm{продуктах,}$ готових до споживання, за винятком продуктів, що призначені для немовлят та спеціальних медичних потреб. Проте Регламент ЄС № 1441/2007 не встановлює обмеження для L. monocytogenes у свіжому м'ясі (Saraiva et al., 2018). За українськими вимогами виявлення L. monocytogenes не допускається у 25 г продуктів (Наказ № 549/9148 від 28.04.2004), проте визначення збудника кількісним методом не нормується.

Рід Listeria включає групу грампозитивних психотрофних бактерій 320 видів: L. monocytogenes,
L. ivanovii, L. innocua, L. welshimeri, L. seeligeri, L. grayi, L. aquatica, L. booriae, L. cornellensis, L. costaricensis, L. goaensis, L. fleischmannii, L. floridensis, L. grandensis, L. marthii, L. newyorkensis, L. riparia, L. rocourtiae, L. thailandensis, L. weihenstephanensis. Серед них L. monocytogenes вважають найважливішим патогеном, який вражає тварин і людей.

Вивчення властивостей Listeria за всіх ймовірних умов допоможе знайти стратегії боротьби 3 цими поширеними бактеріями в харчовій промисловості та продуктах. L. monocytogenes зростає при температурі від $-0,4$ до $50{ }^{\circ} \mathrm{C}$ з оптимальною температурою від 30 до $37^{\circ} \mathrm{C}$, але може рости при $-1,5^{\circ} \mathrm{C}$ у вакуумноупакованій яловичині, що $є$ найнижчою температурою для росту цього мікроорганізму (Hudson, 1992; Wiedmann et al., 2007). Збудник залишається життєздатним в м'ясі індички під час зберігання за температури $18^{\circ} \mathrm{C}$ (Palumbo et al., 1991; Weinsetel, 2006). Вивчали вплив маринування і термічної обробки на стійкість Listeria monocytogenes та Salmonella spp. у курячих грудках (Karyotis et al., 2017).

Грунт, вода, фекальні матеріали і корми для тварин $\epsilon$ резервуаром L. monocytogenes 3 високим ризиком забруднення продукції тваринного і рослинного походження. Статистично доведено, що L. monocytogenes виживає краще у вакуумі, ніж в аеробних умовах, хоча без значної різниці в його здатності виживати за температурою $4{ }^{\circ} \mathrm{C}$ або $9{ }^{\circ} \mathrm{C}$ (Saraiva et al., 2016). Вплив несприятливих умов на мікроорганізми викликає їхню адаптацію і вони стають більш стійкими. Наприклад, адаптація L. monocytogenes до етанолу, голодування, перекису водню і кислоти підвищила стійкість патогена до нагрівання (Bedie et al., 2001; Begley et al., 2002). Така адаптація до факторів навколишнього середовища може знизити ефективність збереження харчових продуктів і обумовити їх небезпечність. Здатність L. monocytogenes вижити в таких суворих умовах також становить великий інтерес для харчової промисловості, оскільки органічні кислоти регулярно використовуються виробниками харчових продуктів для запобігання росту бактерій (Weinsetel, 2006).

Отже, пошук альтернативних підходів до уникнення забруднення, подальшого виживання і зростання L. monocytogenes є важливими запитами м'ясної промисловості.

Вітчизняними вченими вивчається вплив різноманітних речовин на патогенні мікроорганізми, в т. ч. L. monocytogenes (Zazharska \& Ryaba, 2016; Glebenyuk 
et al., 2018; Shcherbyna et al., 2018; Zazharskyi et al., 2018a-d).

Досить високий показник виявлення Listeria spp. 3 продукції, важкий перебіг і наслідки хвороби у людини вимагає розробки нових підходів і критеріїв в системі ветеринарно-санітарного контролю.

Метою роботи було провести аналіз динаміки виявлення і диференціальної ідентифікації Listeria spp. в м'ясопродуктах птахопереробних підприємств Дніпропетровщини.

\section{Матеріал і методи досліджень}

Для проведення моніторингу використовували результати досліджень проб м'яса та м'ясних продуктах птиці, які надавали виробники для мікробіологічного аналізу протягом 11 років. Для проведення досліджень використовували флуоресцентний аналізатор “Mini Vidas", Франція, призначений для автоматизоване визначення мікроорганізмів.

Дослідження проводили у Дніпропетровській регіональній державній лабораторії державної служби України з питань безпечності харчових продуктів та захисту споживачів, яка акредитована Національним агентством акредитації України на компетентність відповідно до вимог ДСТУ ISO/EC 17025 за № 2H192 до 19 червня 2023 р. та має дозвіл на роботу зі збудниками II-IV групи патогенності.

Мікробіологічні дослідження проводили згідно 3 чинними міжнародними нормативними документами ( з 2004 року - ДСТУ ISO 11290-1:2003, з 2017 року ISO 11290-1:2017).

Для ідентифікації Listeria також проводили САМР-тест (названий за прізвищами винахідників Christie-Atkins-Munch-Petersen) на кров'яному агарі 3 еталонними штамами Staphilococcus aureus ATCC № 25923, Rhodococcus ejvi ATCC № 6939, Listeria ivanovi, Listeria innocua ATCC № 33090, Listeria monocytogenes AТCC № 19112. Також біохімічні властивості виділених мікроорганізмів встановлювали за допомогою API-тестів (Analytical profile index - індекс аналітичного профілю - система для швидкої ідентифікації мікроорганізмів) виробництва BioMerieux, Франція. Тільки з 2013 року в лабораторії з'явилась можливість ідентифікувати L. grayi та L. welshimeri за допомогою АРІ-тестів 10300.

\section{Результати та їх обговорення}

Складною проблемою $\epsilon$ виявлення збудника Listeria spp із різних видів матеріалу у зв'язку зі значною контамінацією супутньою мікрофлорою. На загальному мікробному фоні досліджуваного зразка кількість Listeria, зазвичай незначна, тому їх індикація ускладнена.

Ідентифікування Listeria spp за основними видами можливе тільки за біохімічними властивостями - за допомогою API-тестів (рис. 1). Наприклад, під час росту L. іпnосиа спостерігається зміна кольору на рожевий у ферментативному субстраті (DIM - перша луночка знизу) i, навпаки, колір жовтий - при наявноcтi L. monocytogenes.

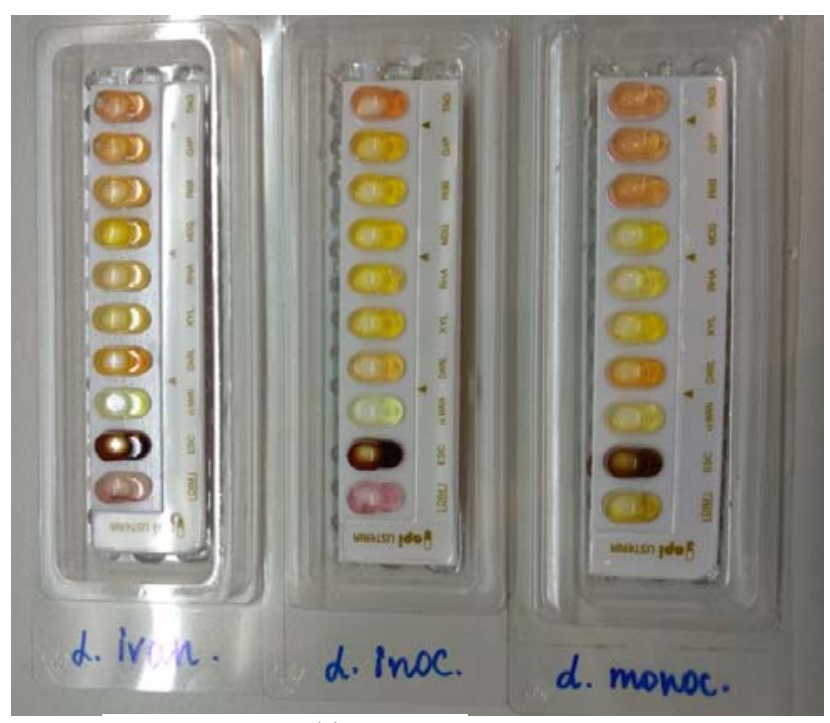

Рис. 1. Ідентифікування L. ivanovi, L. innocua, L. monocytogenes

Аналізуючи кількість проведених досліджень, виявлення та ідентифікації мікроорганізмів у Дніпропетровській області за період 11 років, з 8172 аналізованих проб виявили 3001 позитивних результатів $(36,7 \%)$ (табл. 1). При цьому частка позитивних проб стрімко збільшується 3 8,5\% у 2008 р. до $77,9 \%-$ 2018 р. (рис. 2).

38172 проведених мікробіологічних досліджень за 11 років виділяли L. ivanovii у 1523 зразках $(18,6 \%)$, L. innocua - 833 (10,2\%), L. monocytogenes - $493(6 \%)$, L. seeligeri - 97 (1,2\%). L. grayi - 36 (0,4\%), L. welshimeri у 19 зразках м'ясної продукції (0,2\%).

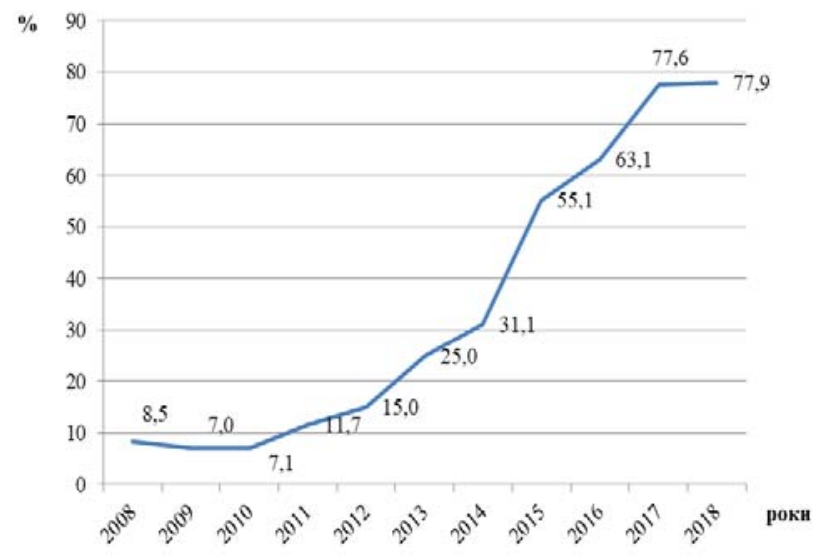

Рис. 2. Частка виявлення Listeria у м'ясі та м’ясних продуктах птиці в 2008-2018 pp. у Дніпропетровській області

3 шести видів ідентифікованих Listeria більше половини складає L. ivanovii, що удвічі більше, ніж випадків L. Innocua, i утричі - порівняно 3 L. monocytogenes (рис. 3). 


\title{
Таблиця 1
}

Виявлення й ідентифікації Listeria у м'ясі та м'ясних продуктах птиці у Дніпропетровській області за 2008-2018 pp.

\begin{tabular}{|c|c|c|c|c|c|c|c|c|c|c|c|}
\hline Нроведено досліджень & 2008 & 2009 & 2010 & 2011 & 2012 & 2013 & 2014 & 2015 & 2016 & 2017 & 2018 \\
\hline Listeria spp. & 508 & 795 & 806 & 711 & 652 & 637 & 801 & 746 & 759 & 803 & 954 \\
\hline \multicolumn{12}{|c|}{ Виявлено позитивних результатів } \\
\hline L. monocytogenes & 1 & 2 & 3 & 4 & 4 & 27 & 35 & 47 & 87 & 104 & 179 \\
\hline L. ivanovii & 25 & 39 & 43 & 58 & 69 & 78 & 103 & 191 & 204 & 301 & 412 \\
\hline L. innocua & 11 & 10 & 8 & 17 & 23 & 48 & 97 & 158 & 168 & 186 & 107 \\
\hline L. seeligeri & 6 & 5 & 3 & 4 & 2 & 3 & 4 & 5 & 7 & 27 & 31 \\
\hline L. grayi & - & - & - & - & - & 2 & 6 & 7 & 9 & 4 & 8 \\
\hline L. welshimeri & - & - & - & - & - & 1 & 4 & 3 & 4 & 1 & 6 \\
\hline Всього & 43 & 56 & 57 & 83 & 98 & 159 & 249 & 411 & 479 & 623 & 743 \\
\hline
\end{tabular}

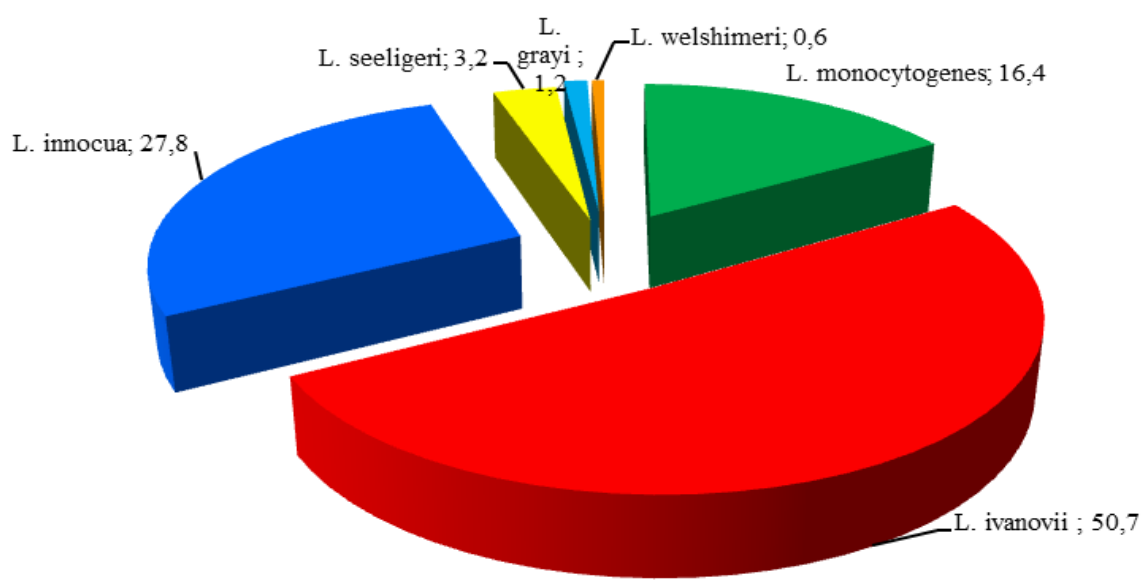

\author{
- L. monocytogenes \\ - L. ivanovii \\ - L. innocua, \\ L. seeligeri \\ L. grayi \\ L. welshimeri
}

Рис. 3. Розподіл Listeria за видами, \%

Також у незначній кількості ідентифікували L. welshimeri, L. grayi, L. seeligeri - від 0,6 до 3,2\%.

L. ivanovii насамперед заражає жуйних тварин (Hupfeld et al., 2015). За іншими даними, до 10\% випадків лістеріозу в овець пов'язані 3 L. ivanovii (McLauchlin, 2011).

Китайськими вченими L. monocytogenes та L. ivanovii були ідентифіковані як єдині два патогенних види в роду Listeria (Wang et al., 2018).

Французькі вчені визнають, що L. monocytogenes, безумовно, $є$ основною причиною лістеріозу людини, але зазначають, що L. ivanovii також широко забруднює м'ясну продукцію і може викликати бактеріємію у пацієнтів зі зниженим імунітетом (Guillet et al., 2010).

Скандинавські вчені виявили Listeria на 11 з 13 птахофабрик, м'ясо- і рибопереробних підприємств. Серед позитивних зразків морепродуктів у 91,1\% випадках ізолювали L. monocytogenes, тимчасом як у м'ясному та птахівницькому секторах - інші види Listeria (переважно L. innocua). Додатково на наявність Listeria досліджували конвеєрні стрічки, підлогу, водостоки, обробні дошки. Трапи і підлоги птахопереробних підприємств виявилися місцями, найбільш контамінованими збудником (Gudbjörnsdóttir et al., 2004).
L. innocua і L. seeligeri ізолювали 3 овочевого i м'ясного відділень у побутових і промислових холодильниках. Автори підкреслюють важливість трьох факторів, пов'язаних 3 ризиком Listeria: контроль температури, харчової упаковки, процедури очищення і дезінфекції (Dieuleveux et al., 2005).

За даними грецьких вчених, 3 51\% позитивних проб замороженого сирого м'яса ізолювали L. monocytogenes, $з$ 49\% - інші види Listeria. Головні джерела первинного забруднення були індичі шиї та грудки, обрізки свинини та шпиг на підприємствах 3 недотриманими гігієнічними вимогами (Samelis et al., 1999). За результатами досліджень L. monocytogenes була ізольована з 12,5\% проб свіжих курячих крильців, тимчасом як понад 42\% були позитивними для всіх видів Listeria (Batt, 1999).

Великих економічних збитків завдає продукція, контамінована збудником Listeria. Компанія Wampler Foods Inc штат Пенсильвания, США відкликала понад 27 мільйонів фунтів продукції з індички та курятини через спалах токсикоінфекції у споживачів, викликаної L. monocytogenes (Voelker, 2002).

Останнім часом проводиться значна робота щодо запобігання спалахам і зменшення захворюваності на лістеріоз. Доведений взаємозв'язок між профілактич- 
ними заходами та зниженням захворюваності на лістеріоз у людини (Troncoso et al., 2009).

\section{Висновки}

Аналізуючи результати моніторингу у Дніпропетровській області за період 11 років, у $36,7 \%$ проб м'яса та м'ясних продуктах птиці виявили Listeria spp. При цьому частка позитивних проб стрімко збільшувалась 3 8,5\% у 2008 р. до 77,9\% - у 2018 р. 3 шести видів ідентифікованих Listeria spp більше половини виявили L. ivanovii, що удвічі більше, ніж випадків L. Innocua, і утричі - порівняно 3 L. monocytogenes. Також у незначній кількості ідентифікували L. seeligeri, L. grayi, L. welshimeri.

Результати моніторингу можуть використовуватись у кількісних оцінках мікробного ризику Listeria spp. на потужностях $з$ переробки м'яса. Виділення Listeria spp. в продукції м'ясопереробних підприємств показує циркуляцію патогенного агента, який може ускладнити епідеміологічну ситуацію з лістеріозу на території Дніпропетровщини.

Перспективи подальших досліджень: вивчити мікробіологічні показники та ветеринарно-санітарну характеристику м'яса за експериментального лістеріозу бройлерів; розробити пропозиції щодо оцінки мікробіологічних ризиків Listeria spp. в м'ясі та м'ясних продуктах.

\section{References}

Arevalos-Sánchez, M., Regalado, C., Martin, S. E., Domínguez-Domínguez, J., \& García-Almendárez, B. E. (2012). Effect of neutral electrolyzed water and nisin on Listeria monocytogenes biofilms, and on listeriolysin $\mathrm{O}$ activity. Food Control, 24(1-2), 116-122. doi: 10.1016/j.foodcont.2011.09.012.

Batt, C.A. (1999). Kluyveromyces. Encyclopedia of Food Microbiology, 1115-1118. doi: 10.1006/rwfm.1999.0865.

Batt, C.A. (2014). Listeria | Listeria monocytogenes. Encyclopedia of Food Microbiology, 490-493. doi: 10.1016/b978-0-12-384730-0.00191-9.

Bedie, G.K., Samelis, J., Sofos, J.N., Belk, K.E., Scanga, J.A., \& Smith, G.C. (2001). Antimicrobials in the Formulation To Control Listeria monocytogenes Postprocessing Contamination on Frankfurters Stored at $4^{\circ} \mathrm{C}$ in Vacuum Packages. Journal of Food Protection, 64(12), 1949-1955. doi: 10.4315/0362-028x64.12.1949.

Begley, M., Gahan, C. G. M., \& Hill, C. (2002). Bile Stress Response in Listeria monocytogenes LO28: Adaptation, Cross-Protection, and Identification of Genetic Loci Involved in Bile Resistance. Applied and Environmental Microbiology, 68(12), 6005-6012. doi: 10.1128/aem.68.12.6005-6012.2002.

Bover-Cid, S., Belletti, N., Garriga, M., \& Aymerich, T. (2011). Model for Listeria monocytogenes inactivation on dry-cured ham by high hydrostatic pressure processing. Food Microbiology, 28(4), 804-809. doi: 10.1016/j.fm.2010.05.005.

Buncic, S., \& Avery, S.M. (2004). Microbiological safety of meat | Listeria monocytogenes. Encyclopedia of Meat Sciences, 804-814. doi: 10.1016/b0-12-464970$\mathrm{x} / 00056-8$.

Dieuleveux, V., Collobert, J., Dorey, F., \& Guix, E. (2005). Surveillance de la contamination par Listeria spp de réfrigérateurs. Sciences Des Aliments, 25(2), 147-155. doi: 10.3166/sda.25.147-155.

Glebenyuk, V.V., Borovik, I.V., Kuchuk, T.V., \& Litvinenko, O.O. (2018). Etiological structure of bacteriosis of animals in the Dnipropetrovsk region for 2014-2016. Scientific Messenger of LNU of Veterinary Medicine and Biotechnologies, 20(83), 260-263. doi: 10.15421/nvlvet8351 (in Ukrainian).

Gray, J.A., Chandry, P.S., Kaur, M., Kocharunchitt, C., Bowman, J.P., \& Fox, E.M. (2018). Novel Biocontrol Methods for Listeria monocytogenes Biofilms in Food Production Facilities. Frontiers in Microbiology, 9, 605. doi: 10.3389/fmicb.2018.00605.

Gudbjörnsdóttir, B., Suihko, M.-L., Gustavsson, P., Thorkelsson, G., Salo, S., Sjöberg, A.-M., ... Bredholt, S. (2004). The incidence of Listeria monocytogenes in meat, poultry and seafood plants in the Nordic countries. Food Microbiology, 21(2), 217-225. doi: 10.1016/s0740-0020(03)00012-1.

Guillet, C., Join-Lambert, O., Le Monnier, A., Leclercq, A., Mechaï, F., Mamzer-Bruneel, M.-F., ... Lecuit, M. (2010). Human Listeriosis Caused by Listeria ivanovii. Emerging Infectious Diseases, 16(1), 136-138. doi: 10.3201/eid1601.091155.

Hudson, J.A. (1992). Efficacy of high sodium chloride concentrations for the destruction of Listeria monocytogenes. Letters in Applied Microbiology, 14(4), 178-180. doi: 10.1111/j.1472-765x.1992.tb00678.x.

Hupfeld, M., Fouts, D.E., Loessner, M.J., \& Klumpp, J. (2015). Genome Sequences of the Listeria ivanovii subsp. ivanovii Type Strain and Two Listeria ivanovii subsp. londoniensis Strains. Genome Announcements, 3(1), e01440-14. doi: 10.1128/genomea.01440-14.

ISO 11290-1:2017 Microbiology of the food chain Horizontal method for the detection and enumeration of Listeria monocytogenes and of Listeria spp. Part 1; Detection method.

ISO 11290-2:2017 Microbiology of the food chain Horizontal method for the detection and enumeration of Listeria monocytogenes and of Listeria spp. Part 2: Enumeration method.

Karyotis, D., Skandamis, P.N., \& Juneja, V.K. (2017). Thermal inactivation of Listeria monocytogenes and Salmonella spp. in sous-vide processed marinated chicken breast. Food Research International, 100, 894-898. doi: 10.1016/j.foodres.2017.07.078.

Kim, S., Ruengwilysup, C., \& Fung, D.Y.C. (2004). Antibacterial Effect of Water-Soluble Tea Extracts on Foodborne Pathogens in Laboratory Medium and in a Food Model. Journal of Food Protection, 67(11), 2608-2612. doi: 10.4315/0362-028x-67.11.2608. 
Marquis, H., Drevets, D.A., Bronze, M.S., Kathariou, S., Golos, T. G., \& Iruretagoyena, J.I. (2015). Pathogenesis of Listeria monocytogenes in Humans. Human Emerging and Re-Emerging Infections, 749-772. doi: 10.1002/9781118644843.ch40.

Martins, E.A., \& Leal Germano, P.M. (2011). Listeria monocytogenes in ready-to-eat, sliced, cooked ham and salami products, marketed in the city of São Paulo, Brazil: Occurrence, quantification, and serotyping. Food Control, 22(2), 297-302. doi: 10.1016/j.foodcont.2010.07.026.

McLauchlin, J. (2011). Listeriosis. Oxford Medicine Online. doi: 10.1093/med/9780198570028.003.0014.

Norwood, D.E., \& Gilmour, A. (2000). The growth and resistance to sodium hypochlorite of Listeria monocytogenes in a steady-state multispecies biofilm. Journal of Applied Microbiology, 88(3), 512-520. doi: 10.1046/j.1365-2672.2000.00990.x.

Palumbo, S.A., \& Williams, A.C. (1991). Resistance ofListeria monocytogenes to freezing in foods. Food Microbiology, 8(1), 63-68. doi: 10.1016/07400020(91)90017-v.

Rizzuto, G.A., \& Bakardjiev, A.I. (2018). Listeria monocytogenes. Oxford Medicine Online. doi: $10.1093 / \mathrm{med} / 9780190604813.003 .0020$.

Samelis, J., \& Metaxopoulos, J. (1999). Incidence and principal sources of Listeria spp. and Listeria monocytogenes contamination in processed meats and a meat processing plant. Food Microbiology, 16(5), 465-477. doi: 10.1006/fmic.1998.0263.

Saraiva, C., García-Díez, J., Fontes, M. da C., \& Esteves, A. (2018). Modeling the Behavior of Listeria monocytogenes in Meat. Listeria Monocytogenes. doi: 10.5772/intechopen.79967.

Schwartz, B., Broome, C., Brown, G., Hightower, A., Ciesielski, C., Gaventa, S., ... Listeriosis Study Group. (1988). Association of sporadic listeriosis with consumption of uncooked hot dogs and undercooked chicken. The Lancet, 332(8614), 779-782. doi: 10.1016/s0140-6736(88)92425-7.

Shcherbyna, R.O., Parchenko, V.V. Safonov, A.A Bushueva, I., Zazharskiy, V.V., Davydenko, P.O., Kulishenko, O.M., Borovic, I.V. (2018) Synthesis and research of the impact of new derivatives of 4-R3(morpholinomethyl)-4H-1，2，4-triazole-5-thiol on cultural attributes of pathogenic M. bovis. Research journal of pharmaceutical biological and chemical sciences, 9(2), 70-79.

Soriano, J.M., Rico, H., Moltó, J.C., \& Mañes, J. (2001). Listeria species in Raw and Ready-to-Eat Foods from Restaurants. Journal of Food Protection, 64(4), 551553. doi: 10.4315/0362-028x-64.4.551.

Troncoso, A., Rebagliati, V., Philippi, R., \& Rossi, M. (2009). Prevention of foodborne listeriosis. Indian Journal of Pathology and Microbiology, 52(2), 145. doi: 10.4103/0377-4929.48903.
Vázquez-Boland, J. A., Kuhn, M., Berche, P., Chakraborty, T., Domínguez-Bernal, G., Goebel, W., ... \& Kreft, J. (2001). Listeria pathogenesis and molecular virulence determinants. Clinical microbiology reviews, 14(3), 584-640.

Voelker, R. (2002). Listeriosis Outbreak Prompts Action-Finally. JAMA, 288(21), 2675. doi: 10.1001/jama.288.21.2675-jmn1204-2-1.

Wang, Y., Wang, Y., \& Ye, C. (2018). Endonuclease restriction-mediated real-time PCR for simultaneous detection of Listeria monocytogenes and Listeria ivanovii. Analytical Methods, 10(11), 1339-1345. doi: 10.1039/c7ay02667f.

Weinsetel, N.A. (n.d.). (2006). Antimicrobial action of selected plant-derived compounds against Listeria monocytogenes. doi: 10.31274/rtd-180813-12172.

Wiedmann, M., \& Sauders, B. (2007). Ecology of Listeria Species and L. monocytogenes in the Natural Environment. Listeria, Listeriosis, and Food Safety, Third Edition, 21-53. doi: 10.1201/9781420015188.ch2.

Zazharska, N.M., \& Ryaba, A.A. (2016). Sanitary quality of goat milk in the application of the homeopathic preparations for milking. Scientific and technical bulletin of State Scientific Research Control Institute of Veterinary Medical Products and Fodder Additives and Institute of Animal Biology, 17(1), 72-77 (in Ukrainian).

Zazharskyi, V.V., Davydenko, P.O., Kulishenko, O.M., Chumak, V.O., Kryva, O.A., Biben, I.A., Tishkina N.M., Borovik, I.V., Boyko, O.O., Brygadyrenko, V.V. (2018a). Bactericidal, protistocidal and nematodicidal properties of mixtures of alkyldimethylbenzyl ammonium chloride, didecyldimethyl ammonium chloride, glutaraldehyde and formaldehyde. Regulatory Mechanisms in Biosystems, 9(4), 540-545. doi: 10.15421/021881.

Zazharskyi, V.V., Davydenko, P.O., Kulishenko, O.M., Borovik, I.V. (2018b). Bacterial properties of ethanol extracts of phytopreparation a staphylococcus spp Bulletin of Veterinary Biotechnology, 32(2), 185-193 (in Ukrainian).

Zazharskyi, V.V., Davydenko, P.O., Kulishenko, O.M., Chumak, V.O., Kryva, O.A., Babaruk, A., Borovik, I.V. (2018c). Comparative assessment of bactericidal properties of disinfectants. Bulletin of the Sumy National Agrarian University, 42(1), 273-276 (in Ukrainian).

Zazharskyi, V. V., Fotina, T. I., Berezovsky, A. V., Davydenko, P. O., Kulishenko, O. M., Chumak, V. O., Kryva, O. A., Borovik, I. V. (2018d). Influence of disinfectants on cryogenic strains of microorganisms. The Journal of the Dnipropetrovsk State Agrarian and Economic University, Veterinary Sciences, 47(1-2), 53-58 (in Ukrainian). 